\title{
Motivation of Secondary School Students to Perform Well in a Test According to its Evaluative Function: The Influence of the Gender Variable ${ }^{1}$
}

\author{
${ }^{1}$ Pascal Ndinga , ${ }^{2}$ Pierre Canisius Kamanzi , ${ }^{3}$ Mamadou Vieux Lamine Sane \\ ${ }^{1}$ Professor, Directeur du département d'éducation ET pédagogie (DEP) (Director of the Department of Education and Pedagogy \\ (DEP)) Université du Québec à Montréal (UQAM) Casse postale 8888, succursale Centre-villeMontréal (Québec) H3C3P8 \\ Canada \\ ${ }^{2}$ Full Professor Faculté des sciences de l'éducation - Département d'administration et fondements de l'éducation (Faculty of \\ Education - Department of Administration and Foundations of Education) Marie-Victorin local A-511 \\ ${ }^{3}$ Directeur du pôle Lettres, sciences humaines ET de l'éducation (Director of the Letters, Humanities and Education cluster) \\ Université Virtuelle du Sénégal (UVS)
}

\begin{abstract}
Summary: This article presents the results of a study comparing girls (81) and boys (74) in grade 8 in high school and their motivation to pass a test based on its evaluative function. The following techniques were used: correlation (r), $\mathrm{t}$-tests for matched samples, Hotelling $\mathrm{T}^{2}$ multivariate and multiple regression test. The results showed that overall, the evaluative function of the test does not affect students' level of motivation to complete it. However, genders showed differing motivation to pass the test based on its evaluative function. In addition the "amotivation" sub-scale could prove to be an effective tool to prevent dropping out, particularly among boys.
\end{abstract}

Key words: Motivation; self-determination; gender; formative assessment; summative assessment.

\section{INTRODUCTION AND PROBLEM STATEMENT}

In recent years, the performance gap between girls and boys has received particular attention from researchers and knowledgeable observers in the world of education (Gibb, Fergusson and Horwood, 2008; van Hek, Kraaykamp, and Wolbers, 2016). In most developed countries, where equal access to education has been ensured for several decades, girls' academic achievement, retention and emotional intelligence are significantly higher than boys' at all levels of education (Spinath, Eckert and Steinmayr, 2014; Fida et al., 2018). Explanations for this phenomenon are diverse and numerous: absence or insufficiency of male role models in schools due to the increasingly low number of men among the teaching staff, challenged by the demands of feminist movements for male culture, related stereotypes (Plante, Théorêt and Favreau, 2010) and roles that historically have been attributed to men, inadequate school structures to stimulate boys, or the overall school experience of girls is said to be more positive than that of boys (Galand, 2004), and so on. Moreover, over time, motivation has emerged as a kind of "dependent" variable that became imperative to consider, as research shows that it has a considerable impact on school performance (Scallon, 1992; Paquet, Carbonneau and Vallerand, 2016). From this perspective, one can wonder whether there is a gender-differentiated motivation to pass a test, depending on its evaluative function. And if so, would this differentiated motivation explain the observed difference between the performance of girls and boys?

The aim of this article is to compare girls and boys in grade 8 in high school in terms of their motivation to perform well on a test according to its evaluative function and to estimate the potential relationship between this motivation and test performance (score). First, we will address the problem, both in terms of the stakes of the tests and the gender-differentiated success rate. Secondly, we will describe the methodology used in this study. Then, third, we will report on the results. The article ends with a discussion in which some avenues of interpretation are proposed.

\footnotetext{
1 The results of this study were initially the subject of a paper at the 72nd ACFAS Congress in 2004. A recent longitudinal study conducted recently (2014-2017) in the Montreal area, the results of which are currently being published, is along the same lines.
} 


\section{Motivation of Secondary School Students to Perform Well in a Test According to Its Evaluative Function: The Influence of the Gender Variable ${ }^{1}$}

\section{THEORETICAL FRAMEWORK}

The tests to which pupils and students are subjected in the educational environment represent a variety of issues. Some are intended for certification; others to diagnose shortcomings in learners; others to collect data for research, and so on. Regardless of the issue at stake, passing the test is a process that requires a certain amount of motivation on the part of the respondent. Studies conducted on this issue have focused, among other things, on the importance given by test takers to assessments that count for the calculation of the cumulative score: the "it matters" principle (Scallon, 1992). Some studies have argued that test scores may be explained, in large part, by the issue associated with the test (Fontaine, 1979; Doyle, 1983; Stedman, 1997; Bracey, 1997). In other words, the higher the stakes of the test, the higher the test score would be.

In terms of evaluation practices, a study by Scallon (1992) revealed that formative evaluation centred on its exclusive function of regulating learning and helping relationships is a better option, as it promotes students' intrinsic motivation. In the new version of the educational success policy, the Ministry of Education and Higher Education (MÉES, 2017) reaffirms the importance of formative evaluation as a crucial practice of quality pedagogy. However, the practice of formative evaluation, with its exclu sive function of regulation and support, is not yet widespread in schools (Cissé, 2015; Conseil Supérieur de l'Éducation (CSÉ), 2018). Generally speaking, situations of intrinsic motivation are rather rare (Pelletier and Vallerand, 1993; Paquet, Carbonneau and Vallerand, 2016).

The frequent use of teaching formulae for large classes in education systems for several years has tended to give greater emphasis to extrinsic motivation to the detriment of intrinsic motivation. In this respect, Delannoy (1997) argues that institutional structures oblige teachers to reward pupils' learning with a large number of marks during the year. This has the effect of subjecting students to pressure and distracting their attention from the learning activities themselves; in other words, a 'teaching-to-test' model is promoted. In fact, "assessment is still generally experienced in a negative way. Because it is often reduced to exams and confused with grading, it still carries a bad reputation and generates mistrust and even anxiety" (CSÉ, 2018, p. 2).

Research shows that extrinsic motivation generally leads to lower performance (lower scores) compared to its counterpart, intrinsic motivation (Vallerand, 1989; Fortier, Vallerand and Guay, 1995; Deci and Ryan, 1985; Cock and Halvari, 1999). According to this research, the only possibility of a positive relationship between extrinsic motivation (external determinant of the issue) and test performance would be if it were self-determined. The individual would, in a way, appropriate the extrinsic dynamic of the test challenge and transmute it into intrinsic motivation, which Vallerand (1993) describes as regulation by identification or integration. Chénier (2018) defines the expression "high-stakes test" as an assessment situation with immediate consequences considered important by the candidate.

In addition, many studies have addressed the issue of differentiating or comparing performance by gender (Spinath, Eckert and Steinmayr, 2014; Fida et al., 2018; Kessels, Heyder, Latsch and Hannover, 2014; Kissau, Kolamo and Wang, 2010). In Quebec, Lavoie (2003) noted the alarming nature of school failure for a majority of boys and a minority of girls. According to this author, special education services serve between three and ten times more boys than girls with behavioural and learning problems. The same author concludes that boys' demotivation and dropping out are increasingly problematic and that solutions must be found.

The superior performance of girls in school compared to boys has become widespread in almost all OECD countries. Tremblay (2000) observes, for his part, that boys and girls have differentiated attributional behaviours with respect to school failure and success. Boys are said to have external attributional behaviour when failing and internal attributional behaviour when succeeding. In other words, they tend to take credit when they succeed and to attribute responsibility to others (teachers, parents, schools, etc.) when they fail. As for girls, they have rather neutral attributional behaviours in many cases. The author notes, moreover, that girls are particularly skilled in language tasks and better than boys in this respect. This superiority of girls in language tasks was also highlighted by the report of the Quebec Ministry of Education ([MEQ], 2004, p.4).

In its report published in 1997, the MEQ had already revealed that the average for girls in a French test at primary school was $75.4 \%$, while the average for boys in the same test was $68.9 \%$. Also in this report, the repetition rate in the first year of secondary school was $12 \%$ for girls and $20 \%$ for boys. The MEQ noted that a link had been established between repeating a year in primary school and the probability of not obtaining a secondary school diploma before the age of 20 . In other words, more boys than girls are in this situation. More than 20 years later, the gap between boys and girls in the success rate in the single ministerial examinations in the grades 6 and 7 remains unchangeable. In fact, figures published by the Ministry of Education and Higher Education (MÉES, 2018) indicate that over the last three years (2016-2017-2018) the pass rate was $88.4 \%, 86.6 \%$ and $89.2 \%$ for boys, respectively, while it was $91.1 \%, 89.3 \%$ and $92.5 \%$. This is, moreover, the conclusion already reached by Théorêt and Hrimech (1999, p. 253): contrary to the previous situation, boys are now over-represented in the statistics on secondary school drop-out compared to girls. According to these researchers, gender-differentiated schooling would explain the differences in the proportion of dropouts by gender. In addition, they found a difference between girls and boys in the importance they attach to the reasons for dropping out of school. For girls, the four basic reasons are, in sequence, failure at school, boredom at school, personal problems and pleasure seeking. For boys, the four basic reasons are, in sequence, boredom at school, pleasure seeking, failure at school and aversion to study. 


\section{Motivation of Secondary School Students to Perform Well in a Test According to Its Evaluative Function: The Influence of the Gender Variable ${ }^{1}$}

Thus, while girls cite failure at school as the primary reason for dropping out, this factor ranks third among boys. The explanation for the difference between girls and boys in the proportion of dropouts through differentiated schooling seems to have had the same resonance with Gagnon (1999, p. 14). According to this author's review of the literature, several studies show that school structures and reinforces sexual differentiation and ultimately establishes a significant link between academic success and gender. According to the MEQ (2004, p. 23), girls generally display behaviours and attitudes that are more conducive to academic success and perseverance than boys. The MEQ (2004, p. 23) thus recommends that means be deployed to support the motivation of certain students. A number of other authors have also studied this phenomenon and come up with similar results (see, for example, Brossard, 1992; Conseil Supérieur de l'Éducation, 1999; Des Rivières, Dufour, 2001; Ouimet, 2001; Pratte, 2001 and Allard, 2004). Recently, a study by Frenette and Zeman (2007), for Statistics Canada, also examined this issue. It sought to explain why most university students are women. The study found that the gap between boys and girls is mainly due to high school grades, work habits and parental expectations, which are higher for girls.

The theory of self-determination (Deci \& Ryan, 1985; Fortier et al., 1995; Ndinga, 2004; Vallerand et al., 1989; Paquet, Carbonneau and Vallerand, 2016) and this empirically observed difference in academic performance between the two genders (Spinath, Eckert and Steinmayr, 2014; Fida et al..., 2018) support the hypothesis that girls are more motivated, either intrinsically or extrinsically, but in a self-determined way. Boys, on the other hand, are said to be only extrinsically motivated. And if such gender-differentiated motivation is confirmed, how far would it explain the observed difference in performance between the two genders? The following section describes the data used and the methodology adopted to answer these questions.

The specific objectives of this study are as follows:

1. to compare the motivation of girls and boys in formative and summative testing situations;

2. to estimate the relationship between their motivation and their performance (score) on the test,

3. to determine the type of motivation that best predicts their performance on the test based on its evaluative function.

\section{DATA SOURCES AND METHODOLOGY}

The data used in this study were collected from January to April 2002 from 155 students (81 girls and 74 boys) in grade 8 in high school in an institution located in Quebec City (Province of Quebec, Canada, commonly referred to as the National Capital Region). Their ages ranged from 13 to 15 years old. According to the socioeconomic environment index established by the Ministry of Education, the school is located in a so-called average socioeconomic environment. The school has close to 1,300 students enrolled in various pathways, including enriched classes, the special pathway, the regular pathway, and special options (available starting in grade 7 in high school). There are a total of six $5^{\text {th }}$ form classes and almost all of them participated in the study. It is a mixed Catholic faith public school of the. However, it also serves students from other religious denominations or with no religious affiliation. The data were collected during a history class.

\section{Measuring instruments}

Two types of measuring instruments were used for data collection. The first is the échelle de motivation à bien réussir un test Motivation Scale to Succeed on a Test (ÉMRT). Originally developed by Ndinga (2004), this scale was reconfirmed in terms of its metric qualities following a meta-analysis of the data by Ndinga and Frenette (2010), while the second is composed of tests on a school discipline, in this case history. The ÉMRT is an instrument composed of three dimensions in particular : (1) selfdetermined motivation (SDM), (2) extrinsic motivation (EM) and amotivation (AM). It consists of a total of 31 items. In terms of internal consistency index values, the three dimensions of the SDM, EM and AM scale have Alpha coefficients of 0.90, 0.90 and 0.90 , respectively, with $\mathrm{n}=327$.

To define these three dimensions, we draw inspiration from Vallerand and O'Connor (Vallerand, 1993). Self-determined Motivation implies choice and self-determination, i.e. the individual displays a sense of direction and meaning, instead of pressure and obligation in the practice of the activity. Consequently, there are no material rewards or constraints. In contrast, extrinsic motivation (EM) refers to the fact that the activity is done under external pressure (obtaining material and social rewards) or constraints to avoid negative consequences (criticism, punishment, etc.). An extrinsically motivated person carries out an activity with the aim of deriving pleasure and personal satisfaction from it or to maintain such a situation (Pelletier and Vallerand, 1993). Amotivation (AM) means the absence of intrinsic and extrinsic motivation; the motivated individual does not perceive the link between his or her actions and the consequences of those actions. There is a perception of lack of control. They act mechanically, automatically, without motivation; hence the term amotivation, (Pelletier and Vallerand, 1993).

As for the second instrument, the tests on a school subject (history), it was designed and developed by the teacher responsible for the classes concerned. These are tests used by the teacher in his or her regular practice. One test was used in formative evaluation (not sanctioned by a mark on the report card) and the other test was used in summative evaluation (sanctioned by a cumulative mark on the report card). In order to verify the existence of a "reasonably" acceptable level of validity (construction) of these tests, the expertise of three teachers in the same school discipline, but from other schools and school boards in the Québec City metropolitan region, was called upon. They were asked to comment on three aspects of the tests (formative test and summative test). In a personalized letter, they were asked three questions. They were asked to say whether or not: (1) the test accurately 
measures the content of the chapter in question in the Secondary II history program; (2) the test covers all the essential elements of the chapter in question; (3) the test questions are developed in a language accessible to Secondary II students. The results of this consultation indicate that the tests appear to have been developed in accordance with the basic principles of the subject. They cover the breadth of the subject matter.

\section{Course of the test}

Respondents were identified by their card number (reference number) usually used at school. They were subjected to two evaluation scenarios corresponding to the two evaluative functions of a history test (formative and summative). For each of these scenarios, they completed an ÉMRT during the 15 minutes prior to the history test. Each student was given a copy of the ÉMRT with his or her card number on it when the test was administered. History test results (both formative and summative) were also recorded by the teacher on lists, one for each class, based on the student's card numbers. This allowed the teacher to correlate their history test scores with their results on the three subscales of the ÉMRT. In this way, not only was the anonymity of respondents ensured, but also the reliability of the matching of the data collected for each topic was ensured. Finally, to ensure the validity of the instruments, each subject was required to have participated in both the formative and summative history tests and to have completed the ÉMRT on both occasions.

\section{Analysis Method}

Pearson's linear correlation (r) was applied to test the intensity of the relationship between the motivation to perform well on a formative test and performance on the one hand, and the relationship between the motivation to perform well on a summative test and performance on the other. In addition, the t-test for paired samples was used to compare students' motivation to perform well on a formative test with their motivation to perform well on a summative test. In addition, given the interrelationships between the three types of motivation (variables), the multivariate T2 Hotelling test for matched samples was used to compare the averages of the two sets of scores on the subscales associated with the two assessment functions of the test. Finally, multiple regression analyses were performed to estimate the relative contribution (standardized regression coefficient Beta) of each independent or explanatory variable to the prediction of the dependent variable (test performance).

\section{Presentation of the results}

The results reveal that, for all subjects, the average level of motivation of students to do well on a formative test is not statistically different from the average level of motivation to do well on a summative test (Tables 1 and 2).

Table 1: Comparison of averages for different types of motivation to perform well on a formative and summative test

\begin{tabular}{|c|c|c|c|c|c|c|c|}
\hline & Average & $\begin{array}{l}\text { Standard } \\
\text { deviation }\end{array}$ & $\begin{array}{l}\text { Difference of } \\
\text { the averages }\end{array}$ & $\begin{array}{c}\text { Standard } \\
\text { error }\end{array}$ & $\mathrm{T}$ & $\mathrm{dl}$ & $\mathrm{p}$ \\
\hline Type of motivation & & & & & & & \\
\hline $\begin{array}{l}\text { Self-determined motivation in } \\
\text { the formative test }\end{array}$ & 35.45 & 8.48 & \multirow[b]{2}{*}{-0.12} & \multirow[b]{2}{*}{6,29} & \multirow[b]{2}{*}{-0.229} & \multirow[b]{2}{*}{155} & \multirow[b]{2}{*}{0.819} \\
\hline $\begin{array}{l}\text { Self-determined motivation on } \\
\text { the summative test }\end{array}$ & 35.56 & 10.10 & & & & & \\
\hline Formative extrinsic motivation & 23.60 & 5.45 & \multirow[t]{2}{*}{-0.29} & \multirow[t]{2}{*}{4.65} & \multirow[t]{2}{*}{$-0,775$} & \multirow[t]{2}{*}{155} & \multirow[t]{2}{*}{0.440} \\
\hline Summative extrinsic motivation & 23.88 & 5.84 & & & & & \\
\hline Motivation in the formative test & 15.13 & 5.48 & \multirow[b]{2}{*}{-0.18} & \multirow[b]{2}{*}{0.41} & \multirow[b]{2}{*}{-0.441} & \multirow[b]{2}{*}{155} & \multirow[b]{2}{*}{0.660} \\
\hline $\begin{array}{c}\text { Motivation in the summative } \\
\text { test }\end{array}$ & 15.31 & 6.51 & & & & & \\
\hline
\end{tabular}

Table 2: Effects of the evaluative function of the test on students' motivation to do well on the test

\begin{tabular}{|c|c|c|c|c|c|c|}
\hline \multicolumn{7}{|c|}{ Multivariate tests $\mathrm{b}(\mathrm{n}=156)$} \\
\hline & & Value & $\mathrm{F}$ & dl of the hypothesis & Error dl & $\mathrm{p}$ \\
\hline \multicolumn{7}{|c|}{ 1) Effect } \\
\hline \multirow{4}{*}{$\begin{array}{c}\text { Originally } \\
\text { ordered }\end{array}$} & Trace of Pilai & 0.006 & $0.306 a$ & 3.000 & 153.000 & 0.821 \\
\hline & Lambda de Wilks & 0.994 & $0.306 a$ & 3.000 & 153.000 & 0.821 \\
\hline & Trace de Hotelling & 0.006 & $0.306 \mathrm{a}$ & 3.000 & 153.000 & 0.821 \\
\hline & Roy's largest root & 0.006 & $0.306 a$ & 3.000 & 153.000 & 0.821 \\
\hline
\end{tabular}


Motivation of Secondary School Students to Perform Well in a Test According to Its Evaluative Function: The Influence of the Gender Variable ${ }^{1}$

\begin{tabular}{|c|c|c|c|c|c|c|}
\hline \multicolumn{7}{|c|}{ 2) Tests of inter-subject effects } \\
\hline Source & Dependent variable & $\begin{array}{c}\text { Sum of type III } \\
\text { squares }\end{array}$ & dl & $\begin{array}{c}\text { Average } \\
\text { of the } \\
\text { squares }\end{array}$ & F & $\mathrm{p}$ \\
\hline $\begin{array}{c}\text { Originally } \\
\text { ordered }\end{array}$ & $\begin{array}{c}\text { Difference in } \\
\text { autonomous motivation }\end{array}$ & 2,077 & 1 & 2,077 & 0,053 & 0,819 \\
\hline & $\begin{array}{c}\text { Difference in extrinsic } \\
\text { motivation }\end{array}$ & 12,981 & 1 & 12,981 & 0,601 & 0,440 \\
\hline & Difference in motivation & 5,026 & 1 & 5,026 & 0,194 & 0,660 \\
\hline
\end{tabular}

$a$ : Accurate statistics; $b$ : Plan: With intercept at the origin (constant); dl: Number of degrees of freedom.

The relationship between motivation to perform well on a formative test and performance differs from that between motivation to perform well on a summative test and performance only in the case of extrinsic motivation (EM) (Table 3). In other words, the evaluative function of the test would only affect the level of students' extrinsic motivation to perform well on a test.

Moreover, only amotivation negatively predicts performance on formative and summative history tests.

Table 3: Pearson correlation coefficients (r) between performance on the formative and summative history tests and the dimensions of the ELT

\begin{tabular}{llll}
\hline & $\begin{array}{l}\text { All } \\
(\mathrm{n}=155)\end{array}$ & Girls $(\mathrm{n}=81)$ & Boys $(\mathrm{n}=74)$ \\
\hline Formative test & & & \\
$\quad$ Self-determined motivation in the formative test & 0.042 & 0.218 & -0.153 \\
$\quad$ Self-determined motivation & -0.073 & 0.177 & -0.047 \\
$\quad$ Extrinsic motivation & $-0.287^{* *}$ & & $-0.339^{* *}$ \\
$\quad$ Summative test & & & \\
$\quad$ Self-determined motivation & 0.044 & 0.087 & 0.001 \\
$\quad$ Extrinsic motivation & $0.169^{*}$ & 0.125 & 0.203 \\
$\quad$ Amotivation & $-0.228^{* *}$ & -0.158 & \\
\hline
\end{tabular}

Also, the evaluative function of the test seems to affect the level of motivation of students differently depending on their gender. Amotivation is negatively associated with the performance of boys in the formative and summative history tests; this phenomenon only appears in the formative history test in the case of girls (Table 4).

Finally, it appears that of the three types of motivation to do well on a test (MDM, EM, and AM), only amotivation (AM) contributes to negatively predicting boys' scores on the history test, in both the formative and summative tests.

Table 4: Linear regression coefficients of performance on formative and summative history tests on motivation to perform well according to gender

\begin{tabular}{|c|c|c|c|c|c|c|c|c|c|}
\hline & \multicolumn{3}{|c|}{ All respondents $(\mathrm{n}=155)$} & \multicolumn{3}{|l|}{ Boys $(n=74)$} & \multicolumn{3}{|c|}{ Girls $(n=81)$} \\
\hline & B & ES & $B$ & B & $\mathrm{ES}$ & $\beta$ & $\mathrm{B}$ & ES & B \\
\hline \multicolumn{10}{|c|}{ 1) Formative test } \\
\hline Like & 0.616 & 0.718 & 0.068 & - & - & - & - & - & - \\
\hline $\begin{array}{l}\text { Self-determined motivation in } \\
\text { the formative test }\end{array}$ & $-7.813 \mathrm{E}-03$ & 0.055 & -0.014 & $-7.137 \mathrm{E}-02$ & 0.084 & -0.119 & $6.262 \mathrm{E}-02$ & 0.076 & 0.122 \\
\hline Self-determined motivation & $1.887 \mathrm{E}-02$ & 0.087 & 0.022 & $-7.645 \mathrm{E}-02$ & 0.135 & -0.084 & $5.998 \mathrm{E}-02$ & 0.115 & 0.075 \\
\hline Extrinsic motivation & -0.241 & 0.068 & $-0.294^{*}$ & -0.300 & 0.095 & $-0.369 *$ & -0.189 & 0.101 & 0.208 \\
\hline $\mathrm{R} 2$ & \multicolumn{3}{|c|}{0.087} & \multicolumn{3}{|c|}{0.147} & \multicolumn{3}{|c|}{0.091} \\
\hline \multicolumn{10}{|c|}{ 2) Summative test } \\
\hline Like & 5.020 & 0.741 & 0.005 & - & - & - & - & 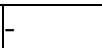 & - \\
\hline
\end{tabular}


Motivation of Secondary School Students to Perform Well in a Test According to Its Evaluative Function: The Influence of the Gender Variable ${ }^{1}$

\begin{tabular}{|l|l|l|l|l|l|l|l|l|l|}
\hline $\begin{array}{l}\text { Self-determined motivation in-2.995 E-02 } \\
\text { the formative test }\end{array}$ & 0.049 & -0.064 & -5.314 E-02 & 0.074 & -0.099 & - & - & - \\
\hline Self-determined motivation & 0.119 & 0.088 & 0.148 & 0.157 & 0.134 & 0.171 & - & - & - \\
\hline Extrinsic motivation & -0.133 & 0.062 & $-0.184^{*}$ & -0.224 & 0.105 & $-0.259^{*}$ & - & - & - \\
\hline R2 & 0.064 & & & 0.116 & & & - & - & - \\
\hline
\end{tabular}

\section{DISCUSSION}

The results of this study lead to a number of observations. First, although statistically significant, the relationship between the score obtained on the history test (both formative and summative) and a motivation is relatively weak. Of the three types of motivation to do well on a test (SDM, EM, and AM), only a motivation (AM) contributes to negatively predicting boys' history test scores on both the formative and summative tests. This finding corroborates the results reported by Vallerand (1989), namely, that a motivation is positively associated with school dropout and predicts the latter prospectively, both in high school (Daoust et al., 1988) and in college (Vallerand \& Bissonnette, 1988a). To this effect, Vallerand (1989, p. 328) points out that when they are a motivated, individuals anticipate not being able to control the results of their actions. They feel disillusioned, wonder why they are doing an activity, and eventually decide to abandon it. The negative association between a motivation and the test score (both formative and summative) of the school subject involved in this research suggests that this could be a plausible indicator of the potential for this eventual drop-out.

A motivation, as a subscale, could prove to be an interesting instrument for the detection of future dropouts, despite the very modest correlations observed in this study. Dropout potential is likely to be detected more in formative than in summative evaluation. In this regard, the absolute values of the correlation coefficients between score and a motivation on the summative test seem higher than those obtained on the formative test. In fact, this latent behaviour among future dropouts may manifest itself more easily in formative assessment, since a formative test is generally perceived as having no impact on the students' immediate school experience. However, by definition, the formative test remains a complementary activity to the summative test insofar as it helps to prepare for it during the teaching-learning phase.

Boys seem to have little sensitivity to the evaluative function of the test, whereas girls would optimize their efforts at the summative test level. It is possible that boys may take summative history tests little or not seriously, while girls may take them more seriously. Girls may be more afraid of failing the summative test than their male peers. This difference between girls and boys seems to illustrate the manifestation of students' intrinsic gender perceptions. In this respect, it is relevant to recall that, according to the work of Théorêt and Hrimech (1999, p. 257), girls attribute their dropping out of school primarily to academic failure, whereas among boys, this reason ranks third after boredom at school and pleasure seeking. The results of the summative test count for the cumulative score, which appears on the report card. However, it is also taken into account in gender performance comparisons. This helps to identify part of the gap in school performance between boys and girls. However, it should not be forgotten that the phenomenon of motivation and its impact on school performance remains rather complex. They are the result of several interacting factors.

In short, it appears that the difference between boys and girls is not in the type of motivation, but in the evaluative function of the test. In contrast to boys, girls would redouble their efforts to perform well on the summative test. Boys are motivated when faced with a history test, whether formative or summative. This situation is observed in girls only in the case of a formative test.

\section{CONCLUSION}

The objective of this study was to compare girls and boys in grade 8 in high school in terms of their motivation to do well on a test according to its evaluative function. Overall, the results obtained show that the evaluative function of the test does not influence the level of motivation of students to do well on a test. However, boys and girls are reported to show different levels of motivation according to the evaluative function of the test. While a motivation is negatively associated with boys' performance on the formative and summative history tests, this association is only observed for girls on the formative history test. This difference between the two groups of students could help to explain the gap in school performance observed between them. However, as the correlation coefficients established from the data used are ostensibly low, additional studies are needed to better understand this phenomenon.

Furthermore, the evaluative function of the test does not seem to affect the direction of the relationship between the score and a motivation either. The latter remains negative in all the cases examined. In this respect, a motivation, as a subscale, could be used as an effective instrument for screening at-risk students with a view to countering academic failure and dropping out, particularly among boys. It would be interesting to consider such an approach in view of the clues that lead us to act in this direction: the 


\section{Motivation of Secondary School Students to Perform Well in a Test According to Its Evaluative Function: The Influence of the Gender Variable ${ }^{1}$}

consistency of the negative correlation with the score (observed in this study) and the positive correlation with "drop-out" factors observed in previous studies (Vallerand, 1989).

\section{Limitations of the Study}

In order to avoid disrupting the regular schedule of student activities as much as possible, we had to insert this research through the teacher's usual practices. In fact, the history tests that were used in formative and summative assessment were designed and produced by the teacher concerned. Furthermore, the test used in formative assessment was not the same as the one used in summative assessment. This made it impossible to compare the results obtained by the students in the formative assessment test with those of their summative assessment test and to exploit the potential information. Finally, and this is what we feel is most important to point out, a major limitation in the interpretation of these results remains the fact that most of the correlation coefficients calculated in this study turn out to be low or even negligible and insignificant. Possible explanations for this situation include the metric qualities of the instruments used, the relatively small number and relative homogeneity of the subjects, and the data collection conditions.

\section{BIBLIOGRAPHY}

1) Allard, M. (2004). CATASTROPHE: Moins d'un garçon sur deux réussit le secondaire en 5 ans. Montréal, Qc: La Presse, mardi, 23 mars 2004.

2) Bouchard, P. ET St-Amant, J.-C. (1996). Les Garçons ET les Filles stéréotypes ET réussite Scolaire. Montréal, QC: Éditions du remue-ménage.

3) Bracey, G. W. (1997). On comparing the incomparable: a response to Baker and Stedman Educational Research, 26(3), 1926.

4) Brossard, L. (1992). Les garçons ont-ils des chances égales de réussir à l'école ? Vie Pédagogique, 80, 20-22

5) Chénier, C. (2018) Étude longitudinale du niveau de sévérité d'examinateurs en français langue étrangère. Thèse de doctorat en éducation Université du Québec à Montréal (UQAM), Qc, Canada

6) Cissé, F. (2015). Appropriation de la politique d'évaluation des apprentissages du Ministère de l'Éducation du Québec, une décennie après son implantation: analyse des pratiques d'évaluation formative d'enseignants montréalais du secondaire. (Mémoire de maîtrise en éducation). Université du Québec à Montréal, Montréal, Canada

7) Cock, D., and Halvari, H. (1999). Relation among achievement motives, autonomy, performance in mathematics, and satisfaction of pupils in elementary school. Psychology Reports, 84(1), 983-997.

8) Conseil supérieur de l'Éducation (1999). Pour une meilleure réussite scolaire des garçons ET des filles. Québec, QC: Conseil supérieur de l'Éducation.

9) Conseil supérieur de l'éducation (2018). Évaluer pour que ça compte vraiment, dans le Rapport 2016-2018: activités, Sainte-Foy, Le Conseil, p. 96.

10) Deci, E. L., and Ryan, R. M. (1985). Intrinsic motivation and self-determination in human behavior. New York, NJ: Plenum Press.

11) Delannoy, C. (1997). La motivation. Centre national de documentation pédagogique. Paris, France: Hachette Éducation.

12) Des Rivières, P. (2001). Les gars ET l'école. Montréal, QC: Le Devoir, 30 novembre 2001.

13) Doyle, W. (1983). Academic Work. Review of Educational Research, 53(2), 159-199.

14) Dufour, V. (2001). L’effort dévalorisé. Montréal, Qc : Le Devoir, 17 novembre 2001

15) Fida, A.; Ghaffar, A.; Zaman, A.; \& Satti, A.N. (2018). Gender Comparison of Emotional Intelligence of University Students. Journal of Education and Educational Developement. 5 (1), June 2018, pp.172-188.

16) Fontaine, F. (1979). Dossier sur l'évaluation. Service pédagogique, Montréal, QC: Presses de l'Université de Montréal.

17) Fortier, M. S., Vallerand, R. J., and Guay, F. (1995). Academic motivation and school performance: toward a structural model. Contemporary Educational Psychology. 20(3), 257-274.

18) Frenette, M. et Zemen, K. (2007). Pourquoi la plupart des étudiants universitaires sont- ils des femmes? Analyse fondé sur le rendement scolaire, les méthodes de travail et l'influence des parents. Ottawa, Ontario: Statistique Canada.

19) Gagnon, C. (1999). Pour réussir dès le primaire : filles et garçons face à l'école. Montréal, QC: les éditions du remueménage.

20) Galand, B. (2004). Le rôle du contexte scolaire et de la démotivation dans l'absentéisme des élèves. Revue des sciences de l'éducation, 30 (1), 2004, 125 - 142

21) Gibb, S. J., Fergusson, D. M. ET Horwood, L. J. (2008). Gender differences in educational achievement to age 25. Australian Journal of Education, 52(1), 63 -80

22) Kessels, U., Heyder, A., Latsch, M. \& Hannover, B. (2014). How Gender Differences in Academic Engagement Relate to Students' Gender Identity. Educational Research. 56 (2), (2014): 220-229 
23) Kissau, S.P., Kolano, L. Q., Wang, C. (2010). Perceptions of Gender Differences in High School Students' Motivation to Learn Spanish. Foreign Language Annals. 43 (4) (Jan - Mar 2010), 703-721

24) Lavoie, G. (2003). L'école au masculin, réduire l'écart de réussite entre garçons et filles, Septembre Éditeur.

25) Ministère de l'Éducation du Québec (2004). La réussite des garçons, des constats à mettre en perspective, Rapport synthèse. Québec, Qc: Gouvernement du Québec.

26) Ministère de l'Éducation ET de l'Enseignement supérieur (2017). Politique de la réussite éducative. Québec : Gouvernement du Québec, p. 84.

27) Ministère de l'Éducation ET de l'Enseignement supérieur (2018). Moyenne et taux de réusite aux épreuves ministérielles uniques en $4^{\mathrm{e}}$ et $5^{\mathrm{e}}$ année du secondaire. Québec : Gouvernement du Québec

28) Motivation pour les personnes Âgés (EMPA). Journal international de psychologie, 1991, 26(2), 219-240.

29) Ndinga, P. (2004). L'incidence de la fonction évaluative du test sur la relation entre la motivation des élèves à bien le réussir et leurs scores. Thèse de doctorat, Université Laval,(Québec).

30) Ndinga, P. et Frenette (2010). Élaboration et validation de l'Échelle de motivation à bien réussir un test (ÉMRT). Mesure et évaluation en éducation, 33(3), 99-123.

31) Ouimet, M. (2001). Écoles : mixtes ou pas? Montréal, Qc : La Presse, 3 mars 2001.

32) Paquet, Y., Carbonneau, N. \& Vallerand, R.J. (2016). La théorie de l'autodétermination, Aspects théorique et appliqués. De Boeck supérieur.

33) Pelletier, L. G. et Vallerand, R. J. (1993). Une perspective humaniste de la motivation: les théories de la compétence et de l'autodétermination. Dans R. J. Vallerand et E. E. Thill (Dir.) : Introduction à la_psychologie de la motivation. Laval, Qc : Éditions Études Vivantes.

34) Plante, I., Théorêt, M., et Favreau, O.E. (2010). Les stéréotypes de genre en mathématiques et en langues : recension critique en regard de la réussite scolaire. Revue des sciences de l'éducation, 36 (2) 2010, p. 389-419

35) Pratte, A. (2001). Les garçons devraient entrer en maternelle UN an après les filles, propose un médecin américain. Montréal, Qc : La Presse.

36) Scallon, G. (1992). L'impact des pratiques évaluatives sur la motivation_des élèves: le pouls de la recherche. Monographies en mesure et évaluation. Département de mesure et évaluation : Université Laval, Sainte-Foy.

37) Spinath, B., Eckert, C. \& Steinmayr, R. (2014). Gender Differences in School Success: What Are the Roles of Students' Intelligence, Personality and Motivation? Educational Research. 56 (2) 230-243.

38) St-Amant, J.-C. (2007). Les garçons et l'école. Montréal, Qc : Sisyphe.

39) Stedman, L. C. (1997). International achievement differences: An assessment of a new perspective. Educational Researcher, 26(3), 4-15.

40) Théorêt, M. et Hrimech, M. (1999). Les paradoxes de l'abandon scolaire : trajectoires des filles et des garçons du secondaire. Revue canadienne de 1 'Éducation, 24(3), 251-264.

41) Tremblay, D. (2000). Motivation scolaire et différences sexuelles : le rôle des attributions causales. Essai de maîtrise inédit, Université Laval, Sainte-Foy.

42) Vallerand, R. J. (1993). La motivation intrinsèque et extrinsèque en contexte naturel : implications pour les secteurs de l'éducation, du travail, des relations interpersonnelles et des loisirs. Dans R. J. Vallerand et E. E. Thill (Dir.) : Introduction à la_psychologie de la motivation. Laval, Qc : Éditions Études Vivantes.

43) Van Hek, M., Kraaykamp, G. et Wolbers, M. H. J. (2016). Comparing the gender gap in educational attainment: the impact of emancipatory contexts in 33 cohorts across 33 countries. Educational Research and Evaluation 22(5-6):260282 